\title{
IMPROVEMENT IN SOYBEAN SPROUTS PRODUCTION WITH ULTRASOUND POWER
}

\author{
VAGNER ALEX MENDES LOSADO ${ }^{1}$ \\ KELI CRISTINA CANTELLI ${ }^{2}$ \\ JULIANA STEFFENS ${ }^{3}$ \\ CLARICE STEFFENS $4^{*}$ \\ MERCEDES CONCÓRDIA CARRÃO-PANIZZI ${ }^{5}$
}

\begin{abstract}
The present work aimed the application of different ultrasound powers $(10,50$ and $90 \mathrm{~W})$ to evaluate the germination and characteristics of soybean sprouts from soybeans of cultivar BRS 216 and 3 lines $(A, B$ and $C)$. In the germination test, the line $A$ showed the highest percentage of germination ( $96 \%$ for $90 \mathrm{~W}$ ). The cultivar BRS 216 and line A present lower values of weight and higher yield of sprouts. The viable sprouts that presented the highest weight (for each $50 \mathrm{~g}$ of soybean) were: line A followed by BRS 216, line C and B, with statistical differences $(p<0.05)$ between them. For each $50 \mathrm{~g}$ of soybean of cultivar BRS 216 and Lines A, B and C the production of viable sprouts was $231.47 ; 237.87 ; 170.74$ and $199.94 \mathrm{~g}$, respectively, for $90 \mathrm{~W}$. In relation to the length of the sprouts using the power of $10 \mathrm{~W}$ the line $\mathrm{C}$ presented a longer length. The line A using $90 \mathrm{~W}$ showed better color characteristics. The highest protein value was found in cultivar BRS 216, for all applied potencies. With this work it can be concluded that the line A would be the most suitable for sprout production regardless of the ultrasound power applied.
\end{abstract}

KEY WORDS: CULTIVAR, GERMINATION, PROTEIN, POWER.

1 Bacharel em Engenharia de Alimentos, Engenharia de Alimentos, Universidade Regional Integrada do Alto Uruguai e das Missões, Programa de Pós Graduação em Engenharia de Alimentos, CEP 99700-000, Erechim/RS, Brasil. E-mail: vaguialex@hotmail.com

2 MSc. em Engenharia de Alimentos. Pós Graduação em Engenharia de Alimentos, Universidade Regional Integrada do Alto Uruguai e das Missões, Programa de Pós Graduação em Engenharia de Alimentos, CEP 99700-000, Erechim/RS, Brasil. E-mail: keli.cantelli@hotmail.com

3 Doutora em Engenharia Quimica. Universidade Regional Integrada do Alto Uruguai e das Missões, Programa de Pós Graduação em Engenharia de Alimentos, CEP 99700-000, Erechim/RS, Brasil. E-mail: julisteffens@ uricer.edu.br

4 Doutora em Engenharia de Alimentos. Universidade Regional Integrada do Alto Uruguai e das Missões, Programa de Pós Graduação em Engenharia de Alimentos, CEP 99700-000, Erechim/RS, Brasil. E-mail: clarices@uricer.edu.br

5 Doutora em Ciências de Alimentos. Empresa Brasileira de Pesquisa Agropecuária (Embrapa) - Passo Fundo, RS, Brazil. Email: mercedes.panizzi@embrapa.br 


\section{INTRODUCTION}

Brazil is the second largest producer of soybeans in the world, behind only of the United States. Soybeans are one of the most important Brazilian commodities. In the 2013/2014 crop season 86.120.8 million tons of soybeans were harvested, while in the 2014/2015 crop season the production was 96.222 .1 million tons. For the 2015/2016 harvest, the estimate is for growth in production and productivity, reaching 102.1 million tons and for the next years it is expected an even higher production (CONAB, 2015).

Soybeans contains several bioactive constituents, such as isoflavones, protease inhibitors, saponins and phytic acids. Its health benefits have been investigated, either because of its high protein content of nutritional quality or because of its significant content in minerals and fibers, or because of its content of phenolic compounds or polyphenols, which are secondary metabolites of plants, with different chemical structures, presenting an extensive antioxidant action and consequently beneficial health effects (MARTINEZ et al. 2011).

Among the soybean derivatives, sprouts stand out because they are rich in dietary fiber, nutrients and bioactive components (YANG et al, 2015). Sprouts are obtained from germinated beans by contact with water, air and heat. According to Vieira and Lopes (2001), the germination process does not require direct sunlight, is produced in a short time, and with up to six days is possible harvest sprouts with size suitable for consumption. With germination, some significant changes occur in the centesimal composition in soybean grains. Germination is the simplest and most economical way of improving the nutritional value of grains, besides reducing antinutritional factors and increasing digestibility (LOURES et al. 2009).

To guarantee the sprouts quality, grains with high germinative vigor are required. It is interesting to make use of technologies that aid in the stimulation of germination, where the ultrasound is presented as an alternative, accelerating the absorption of water in the grains (MIANO et al. 2016), besides being considered a safe process, non-toxic and environmentally correct.

The most common interaction mechanism involved in ultrasonic technology is cavitation that causes thermal and chemical effects. In addition, mechanical effects, causing shock waves, can also accelerate the water absorption into grains by ultrasound. Although ultrasound treatment has been applied to stimulate germination in many different types of grains, little information is available on the effects of ultrasound on germinated grains in the food science view (YANG et al. 2015).

In Brazil the production of soybean sprouts is still very restricted or almost non-existent. Therefore, studies are needed to improve the production and germination of the sprouts, as for example the application of ultrasound in grains before germination. Embrapa Soja has developed new soybean cultivars and lines genetically improved with small grains to be used in the production of sprouts. In this sense, this work aimed the use of these lines with application of ultrasound power to verify the germination and obtaining soybean sprouts, in addition characterize physical and chemical.

\section{MATERIAL AND METHODS}

\subsection{SOYBEANS}

Soybeans (Glycine $\max$ (L.) Merrill) of cultivar BRS 216 and of 3 lines (A, B and C) of National Soybean Research Center - Embrapa, Londrina, PR in 2014/2015 crop seasons were used for sprout production, were the grains where produced in Passo Fundo/RS.

\subsection{SOYBEAN QUALITY ANALYSIS}

For soybean sprout production, it is important to evaluate the grains quality. For this, it was evaluated the weight of 100 grains and the germination test was carried out according to Brazil 
(1992). For the evaluation of the weight of 100 grains, were separated randomly three samples with 100 grains of all the soybeans, were weighed in a precision scale $(0.001 \mathrm{~g})$ (before and after germination), and the analyzes were performed in triplicate.

In the germination analysis, four replicates of 100 grains were used. The grains were counted manually, inserted in vials with $500 \mathrm{~mL}$ of distilled water, for the treatment in ultrasonic bath (Unique, Model USC-1800A, $40 \mathrm{kHz}$ ). Subsequently, different ultrasonic powers (10, 50, and $90 \mathrm{~W}$ ) were applied for $30 \mathrm{~min}$ at $25^{\circ} \mathrm{C}$ (YANG et al. 2015). Next, the grains were seeded in humid paper towel and placed in a chamber at $25{ }^{\circ} \mathrm{C}$ and $99 \%$ of relative humidity. After 4 days, the sprouts were counted and the results expressed in percentage.

\subsection{SPROUTING}

The soybeans were visually selected, removing toothpicks, stones, wilted and cracked grains. $50 \mathrm{~g}$ of soybeans (cultivar BRS 216 and lines A, B and C) were sanitized with sodium hypochlorite $(1 \%)$ for $4 \mathrm{~min}$. For the ultrasound treatment, these grains were placed in a glass Becker containing $500 \mathrm{~mL}$ of distilled water and exposed to different power (10,50 and $90 \mathrm{~W}$ ), for $30 \mathrm{~min}$, at $25^{\circ} \mathrm{C}$. Next, the soybeans were immersed in water for $4 \mathrm{~h}$ at $25^{\circ} \mathrm{C}$ (OLIVEIRA 2013, adapted of EMATER, 2007).

The soybeans were placed into plastic trays $(35 \mathrm{~cm}$ of diameter) with holes in the bottom to drain the water after irrigation and kept in the dark at $25^{\circ} \mathrm{C}$ and $99 \%$ of relative humidity to sprout. The irrigation was conducted every $12 \mathrm{~h}$, spraying $25 \mathrm{~mL}$ of water at $25^{\circ} \mathrm{C}$. Sprouting was stopped by removing the samples after 4 days, time needed to reach approximately $7 \mathrm{~cm}$ (CANTELLI et al. 2016).

The sprouts were physically analyzed in relation to length, weight and color. The length of the sprouts was measured using a pachymeter (Starrett ${ }^{\mathrm{TM}}$ model Universal Series 125), in triplicate, for each type of grain studied. The weight of the viable sprouts (from $50 \mathrm{~g}$ of grains) was determined with precision scale $(0.001 \mathrm{~g})$ and the results expressed in $\mathrm{g}$.

Instrumental color was determined using a colorimeter (Minolta CR400), with light source D65, expressing the results in the Lab color space $\left(L^{*} a^{*} b^{*}\right)$. Equipment calibration was carried out using a standard white plate. The samples were placed in a Petri dish $(9 \mathrm{~cm}$ diameter) using the amount of sample necessary to cover completely the bottom of the dish. All the measurements were carried out in triplicates.

For the chemical analysis of humidity and protein, the sprouts were previous freezing in ultra-freezer (Indrel IUT 355D) at $-80^{\circ} \mathrm{C}$, and after lyophilized (Edwards $\AA$, Modulyon model) at $-40^{\circ} \mathrm{C}$ for $72 \mathrm{~h}$. Later, the sprouts were milled in a Cuisinart ${ }^{\circ}$ grinder (model DCG-20BKN), and stored in plastic bottles and kept in a refrigerator $\left(10^{\circ} \mathrm{C}\right)$. Humidity was determined by gravimetric method at $105^{\circ} \mathrm{C}$ for $4 \mathrm{~h}$, until constant weight (AOAC, 2000). The total protein was determined by Kjeldahl method, according to methodology AOAC (2000).

\subsection{STATISTICAL ANALYSIS}

The results of the physical and chemical analyses were subject to Tukey's test at $5 \%$ significance for comparison between the means. Principal component analysis (PCA) between the parameters length, weight, humidity and protein were applied to examine the interrelationships of the experiments. All statistics analysis were performed using Statistic 5.0 (StatSoft Inc®, USA) software.

\section{RESULTS AND DISCUSSION}

\subsection{PHYSICAL AND PHYSIOLOGICAL QUALITY OF SOYBEAN}

The soybeans of cultivar BRS 216 and of 3 lines (A, B and C) were evaluated in relation to quality for sprouts production, which are the germination percentage and the weight of 100 grains (Table 1). 


\section{TABLE 1: GERMINATION AND WEIGHT OF 100 SOYBEANS (INITIAL AND END) OF CULTIVAR BRS 216 AND OF 3 LINES (A, B AND C) USING DIFFERENT ULTRASONIC POWER.}

\begin{tabular}{cccccc}
\hline Cultivar & Power & Germination (\%) & Initial Weight (g) & End Weight (g) & Yield (\%) \\
& $10 \mathrm{~W}$ & $83^{\mathrm{C}} \pm 0.60$ & $9.91^{\mathrm{A}} \pm 0.65$ & $37.80^{\mathrm{B}} \pm 0.41$ & 73.78 \\
$\mathrm{BRS} 216$ & $50 \mathrm{~W}$ & $86^{\mathrm{B}} \pm 0.56$ & $8.91^{\mathrm{A}} \pm 0.55$ & $36.96^{\mathrm{B}} \pm 0.75$ & 75.89 \\
& $90 \mathrm{~W}$ & $88^{\mathrm{A}} \pm 0.86$ & $9.06^{\mathrm{A}} \pm 0.35$ & $41.92^{\mathrm{A}} \pm 0.30$ & 78.39 \\
& $10 \mathrm{~W}$ & $91^{\mathrm{C}} \pm 0.90$ & $9.91^{\mathrm{A}} \pm 0.70$ & $40.00^{\mathrm{B}} \pm 0.80$ & 75.23 \\
Line A & $50 \mathrm{~W}$ & $94^{\mathrm{B}} \pm 0.53$ & $8.81^{\mathrm{A}} \pm 0.76$ & $39.18^{\mathrm{B}} \pm 0.67$ & 77.51 \\
& $90 \mathrm{~W}$ & $96^{\mathrm{A}} \pm 0.48$ & $9.56^{\mathrm{A}} \pm 0.68$ & $43.58^{\mathrm{A}} \pm 0.72$ & 78.06 \\
& $10 \mathrm{~W}$ & $68^{\mathrm{C}} \pm 0.47$ & $14.80^{\mathrm{A}} \pm 0.87$ & $34.68^{\mathrm{C}} \pm 0.43$ & 57.32 \\
Line B & $50 \mathrm{~W}$ & $70^{\mathrm{B}} \pm 0.65$ & $12.66^{\mathrm{A}} \pm 1.40$ & $36.71^{\mathrm{B}} \pm 0.87$ & 65.51 \\
& $90 \mathrm{~W}$ & $78^{\mathrm{A}} \pm 0.85$ & $13.15^{\mathrm{A}} \pm 0.86$ & $44.90^{\mathrm{A}} \pm 0.38$ & 70.71 \\
& $10 \mathrm{~W}$ & $79^{\mathrm{C}} \pm 0.96$ & $12.84^{\mathrm{A}} \pm 0.75$ & $43.77^{\mathrm{B}} \pm 0.53$ & 70.66 \\
Line C & $50 \mathrm{~W}$ & $82^{\mathrm{B}} \pm 0.39$ & $11.31^{\mathrm{A}} \pm 0.93$ & $41.52^{\mathrm{C}} \pm 0.70$ & 72.76 \\
& $90 \mathrm{~W}$ & $84^{\mathrm{A}} \pm 0.43$ & $12.21^{\mathrm{A}} \pm 0.73$ & $48.83^{\mathrm{A}} \pm 0.65$ & 74.99 \\
\multicolumn{2}{l}{ Means ( \pm standard deviations) followed by same letters on columns (same cultivar) } & & & &
\end{tabular}

The germination test is used to evaluate the physiological quality of the grains and allows knowing the germination potential of a batch under favorable conditions, that is, suitable conditions for each type of grain (CARVALHO and NAKAGAWA, 2000). The line A presented the highest percentage of germination ( $96 \%$ to $90 \mathrm{~W}$ ), differing statistically from the others ultrasonic powers $(p<0.05)$ used for this line. It was verified that with the increase of the ultrasonic power increase the germination, probably this is due ultrasonic waves travel through the product increase the mass transfer promoting the hydration. This also affects the biological system accelerating the germination.

After germination, all grains submitted to $90 \mathrm{~W}$ presented statistically greater weight and yield, than those with 50 and $10 \mathrm{~W}$. The lines $B$ and $C$ present greater weight, indicating larger size of the grains. However, the cultivar BRS 216 and line A presented lower values of weight, but a higher yield of sprouts. Taking into account that smaller grains are desirable for the production of sprouts, cultivar BRS 216 and line A are more suitable for this purpose. In addition, the grains must be of quality, with high physical purity, without contamination (VIEIRA and LOPES, 2001).

\subsection{SPROUTS CHARACTERIZATION}

Table 2 shows the results of the viable sprouts of BRS 216 and line A, B and C, germinated for 4 days, applying different ultrasound power before germination.

According to the Table 2, the viable sprouts with high weight (for each $50 \mathrm{~g}$ of soybean), were the line A, followed by BRS 216, line $C$ and B, with statistical differences $(p<0.05)$ between the cultivars. A significant difference $(p<0.05)$ was observed for the same cultivar in different ultrasonic powers, as well as in the different cultivars using the same ultrasound power. Oliveira et al., (2013) produced soybean sprouts from cultivar BRS 216 , using $25 \mathrm{~g}$ of soybean grains, with five days of germination obtained $35.73 \mathrm{~g}$ of viable sprouts; with six days $43.12 \mathrm{~g}$, and seven days $64.19 \mathrm{~g}$, regardless of irrigation frequency each $12 \mathrm{~h}, 27.5 \pm 5.1^{\circ} \mathrm{C}$ of temperature and relative humidity $(53.5$ $\pm 16.5 \%$ ). Thus, it can be seen that BRS 216 sprouts, germinated for 4 days showed much higher weight than those obtained by Oliveira et al., (2013) with 5 days of germination, indicating that in the present work there was a significant weight increment with using ultrasonic power. 
TABLE 2: WEIGHT (G) AND LENGTH (CM) OF SOYBEANS SPROUTS OF CULTIVAR BRS 216 AND OF 3 LINES (A, B AND C) USING DIFFERENT ULTRASONIC POWERS.

\begin{tabular}{|c|c|c|c|}
\hline \multirow{2}{*}{ Cultivar } & \multicolumn{3}{|c|}{ Ultrasonic power } \\
\hline & $10 \mathrm{~W}$ & $50 \mathrm{~W}$ & $90 \mathrm{~W}$ \\
\hline \multicolumn{4}{|c|}{ Weight (g) } \\
\hline BRS 216 & $190.71^{\mathrm{Cb}} \pm 1.2$ & $207.42^{\mathrm{Bb}} \pm 1.4$ & $231.47^{\mathrm{Ab}} \pm 1.4$ \\
\hline Line A & $216.90^{\mathrm{Ca}} \pm 1.5$ & $222.30^{\mathrm{Ba}} \pm 1.6$ & $237.87^{\mathrm{Aa}} \pm 2.1$ \\
\hline Line B & $117.17^{\mathrm{Cd}} \pm 1.7$ & $144.96^{\mathrm{Bd}} \pm 2.2$ & $170.74^{\mathrm{Ad}} \pm 1.2$ \\
\hline Line C & $170.25^{\mathrm{Cc}} \pm 1.1$ & $183.60^{\mathrm{BC}} \pm 1.7$ & $199.94^{\mathrm{AC}} \pm 1.7$ \\
\hline \multicolumn{4}{|c|}{ Length $(\mathrm{cm})$} \\
\hline BRS 216 & $12.3^{\mathrm{Ab}} \pm 1.4$ & $6.9^{\mathrm{Ba}} \pm 1.2$ & $11.4^{\mathrm{Aa}} \pm 1.3$ \\
\hline Line A & $10.7^{\mathrm{Bb}} \pm 1.2$ & $9.1^{\mathrm{Ba}} \pm 1.4$ & $14.0^{\mathrm{Aa}} \pm 2.0$ \\
\hline Line B & $10.8^{\mathrm{Ab}} \pm 1.9$ & $9.2^{\mathrm{Aa}} \pm 2.0$ & $7.5^{\mathrm{Bb}} \pm 1.1$ \\
\hline Line C & $15.8^{\mathrm{Aa}} \pm 1.2$ & $8.4^{\mathrm{Ba}} \pm 1.4$ & $9.0^{\mathrm{Bb}} \pm 1.6$ \\
\hline
\end{tabular}

Means ( \pm standard deviations) followed by same uppercase letters on the line and lower case letters on columns represents no significant difference at $5 \%$ level (Tukey's test).

Cantelli et al. (2017), evaluating the weight of soybean sprouts under the same conditions of the present study, also using cultivar BRS 216 and lines A, B and C of the 2014/2015 crop, but without application of ultrasound power, obtained values of $140.93 ; 214.36 ; 60.70$ and $67.62 \mathrm{~g}$, respectively. Thus, comparing the results with the present study, the application of ultrasound power before the germination increased the product weight.

The soybean sprouts from Line $C$ presented a longer length using $10 \mathrm{~W}$, differing statistically $(p<0.05)$ of the others (Table 2). At $50 \mathrm{~W}$, there was no significant difference $(p>0.05)$ between the cultivars. Using $90 \mathrm{~W}$ the BRS 216 and line A were the ones that presented greater length differing statistically $(p<0.05)$ of the others. Comparing the lengths of the sprouts in different powers, it is verified that the same did not follow a trend among them, presenting different behaviors, characteristics of each cultivar. Figure 1 shows the lengths of soybean shoots on the $4^{\text {th }}$ day of germination.

FIGURE 1. ILLUSTRATIVE IMAGE OF THE LENGTH (CM) OF SOYBEANS SPROUTS FROM CULTIVAR BRS 216 AND 3 LINES (A, B AND C).

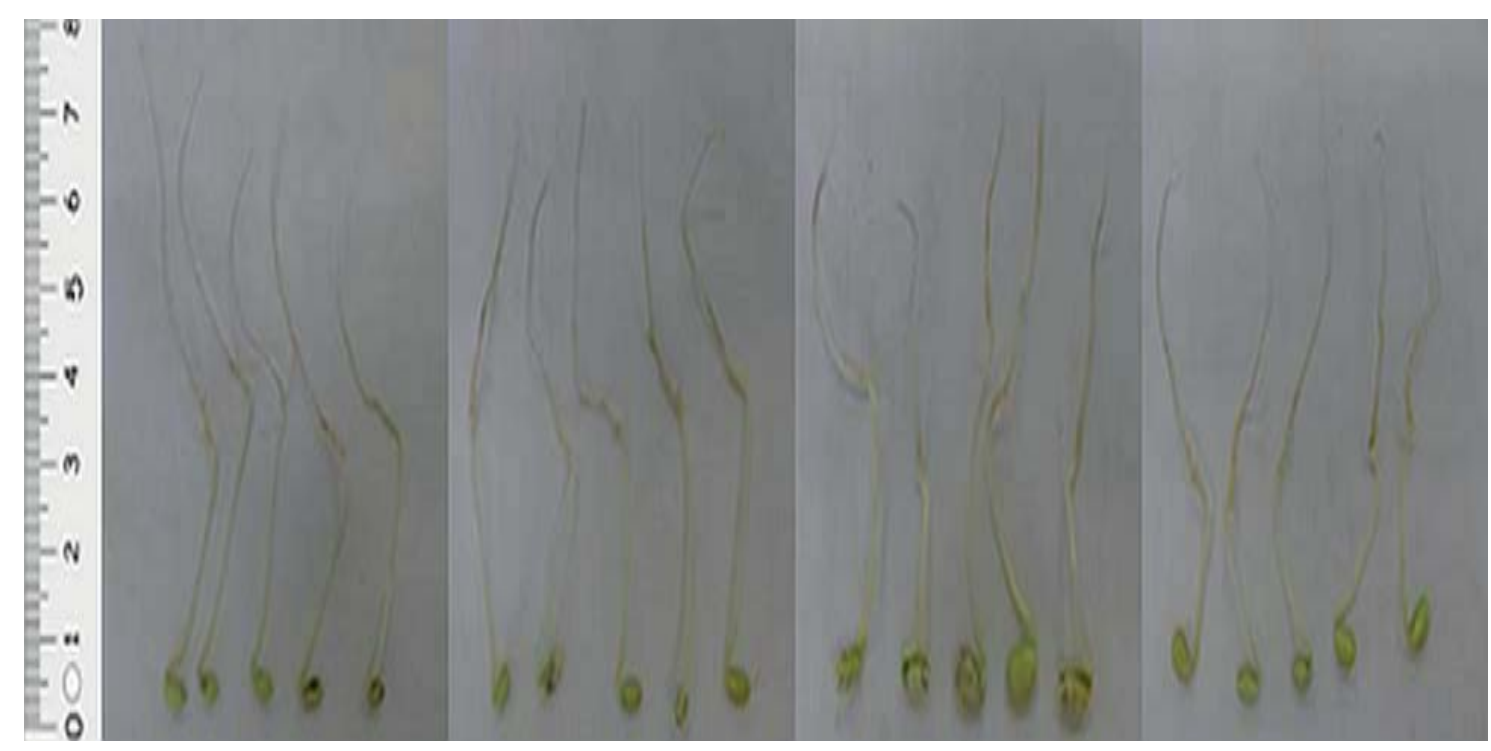


Oliveira et al. (2013) found length values of $7.74,11.11$ and $13.77 \mathrm{~cm}$ for soybean sprouts from cultivar BRS 216, germinated for five, six and seven days, respectively, with irrigation frequency of $12 \mathrm{~h}$. Vilas Boas et al., (2002), studying the average length of soybean sprouts, observed values ranging from $4.30 \mathrm{~cm}$ ( 3 days of germination) to $9.80 \mathrm{~cm}$ (6 days of germination). The differences in weight and length found among the soybean sprouts studied in the present work are expect, since they are different lines, which present different genetic characteristics.

The protein and humidity contents, in the soybean sprouts from cultivar BRS 216 and lines $A, B$ and $C$, are present in Tables 3 . The sprouts with the highest protein value were those from cultivar BRS 216, for all ultrasonic power studied, presenting a significant difference $(p<0.05)$ of the other cultivars. These differences in protein content can be attributed to the genetic differences between soybean cultivars, the stage of development in which the grains were harvested and the climatic conditions (Silva, 2009). According to the Brazilian Food Composition Table - TACO (2011), soybean has around $36 \%$ of protein content, black beans $(21.3 \%)$, peas in pods $(7.5 \%)$ and peanuts $(27.2 \%)$, in this way the soybean highlights in relation to the other leguminous in relation to protein.

\section{TABLE 3: VALUES OF PROTEIN (G/100G) AND HUMIDITY (G/100G) OF SOYBEANS SPROUTS FROM CULTIVAR BRS 216 AND 3 LINES (A, B AND C) USING DIFFERENT ULTRASONIC POWERS.}

\begin{tabular}{cccc}
\hline Cultivar & \multicolumn{3}{c}{ Ultrasonic power } \\
& $\mathbf{1 0} \mathbf{~}$ & $\mathbf{5 0 ~ W}$ & $\mathbf{9 0} \mathbf{~ W}$ \\
& & Protein $(\mathbf{g} / \mathbf{1 0 0} \mathbf{g})$ & \\
BRS 216 & $40.7^{\mathrm{Ba}} \pm 0.4$ & $42.1^{\mathrm{Ba}} \pm 1.1$ & $43.8^{\mathrm{Aa}} \pm 0.1$ \\
Line A & $38.1^{\mathrm{Bb}} \pm 1.5$ & $38.3^{\mathrm{Bb}} \pm 0.3$ & $42.5^{\mathrm{Ab}} \pm 0.8$ \\
Line B & $37.4^{\mathrm{Bb}} \pm 2.1$ & $38.1^{\mathrm{Bb}} \pm 0.2$ & $40.6^{\mathrm{Ac}} \pm 0.4$ \\
Line C & $38.4^{\mathrm{Ab}} \pm 1.1$ & $38.5^{\mathrm{Ab}} \pm 0.7$ & $39.0^{\mathrm{Ac}} \pm 1.4$ \\
& & Humidity $(\mathbf{g} / 100 \mathrm{~g})$ & \\
BRS 216 & $78.5^{\mathrm{Bb}} \pm 0.6$ & $79.2^{\mathrm{Ba}} \pm 0.4$ & $80.4^{\mathrm{Ab}} \pm 0.2$ \\
Line A & $75.4^{\mathrm{Cc}} \pm 0.1$ & $80.4^{\mathrm{Ba}} \pm 0.9$ & $81.8^{\mathrm{Aa}} \pm 0.3$ \\
Line B & $72.7^{\mathrm{Ad}} \pm 1.1$ & $73.4^{\mathrm{Ac}} \pm 0.1$ & $75.1^{\mathrm{Ac}} \pm 2.3$ \\
Line C & $77.0^{\mathrm{Bc}} \pm 2.3$ & $78.4^{\mathrm{Bb}} \pm 1.0$ & $80.9^{\mathrm{Aa}} \pm 1.2$ \\
\hline
\end{tabular}

Means ( \pm standard deviations) followed by same uppercase letters on the line and lower case letters on columns represents no significant difference at $5 \%$ level (Tukey's test).

Ultrasonic power of 10 and $50 \mathrm{~W}$ not have significant difference on the protein content, in the same cultivar. With the increase to $90 \mathrm{~W}$, a significant difference $(p<0.05)$ was observed among cultivars, except for line $\mathrm{C}$. These differences in the protein content can be explained by the traveling of ultrasonic wave through the soybean, which causes the expansion and compression of the medium (MIANO et al. 2016a). The acoustic cavitation can change the product structure that resulted in high protein content.

The increase content of protein in the germinated soybean occurs due to protein enzymatic synthesis or the change in composition following the degradation of other constituents (Martinez et al., 2011; Barcelos et al., 2002).

With the application of ultrasound power in the soybean germination is observe the trend of increasing humidity content with increased of ultrasonic power (Table 3). Line A presented 
high humidity content for $50 \mathrm{~W}$ and $90 \mathrm{~W}$ with values of 80.4 and $81.8 \%$. This result can be explained, because during the germination process the hydration of the grains occurs in order to promote the growth of the plant (VILLELA et al. 2007). The ultrasound process could to affect the porosity of the soybean, increases the water intake by pumping the water into the tissues and by unblocking the pores (MIANO et al. 2017). According to Miano et al., (2016b) related that the ultrasonic waves facilitating the acoustic cavitation and the formation of micro cavities, thus causes a change in the pores size or shape that improve the mass transfer.

According to PCA analysis (Figure 2) showed that the first and second principal components explained, respectively, $85.2 \%$ and $10.7 \%$ and influenced the separation of the cultivars. Evaluating the parameters of weight, length, protein and humidity in soybean sprouts, this analysis could classify the cultivars. These groupings were due to the fact of genetic differences of the cultivars, since the germination conditions were identical.

\section{FIGURE 2. PRINCIPAL COMPONENT ANALYSIS OF WEIGHT, LENGTH, PROTEIN AND HUMIDITY IN SOYBEAN SPROUTS.}

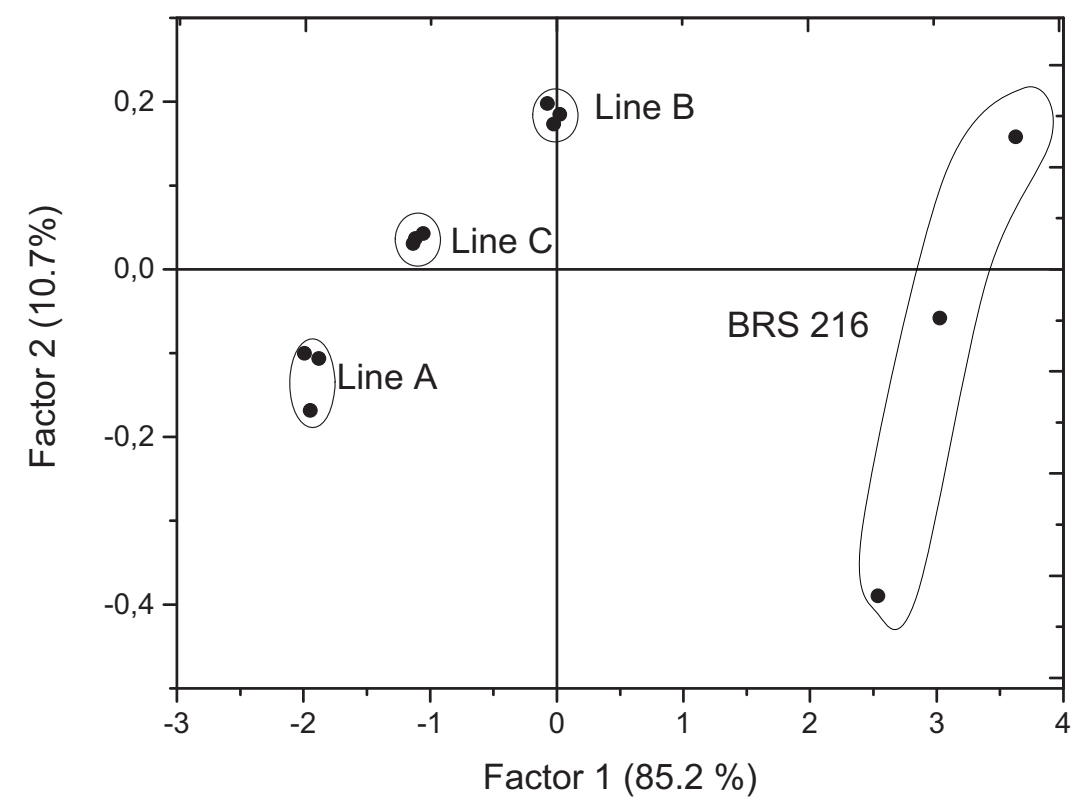

The results of color of the soybean sprouts germinated for 4 days, using irrigation frequency every $12 \mathrm{~h}$, are present in Table 4 . It was evaluated the color coordinates, such as brightness $\mathrm{L}^{*}$ (lighter or darker sample), $a^{*}$ (red and green difference) and b* (blue and yellow difference).

TABLE 4: COLOR OF SOYBEANS SPROUTS FROM CULTIVAR BRS 216 AND 3 LINES (A, B AND C) USING DIFFERENT ULTRASONIC POWERS.

\begin{tabular}{|c|c|c|c|c|c|c|c|c|c|c|c|c|}
\hline \multirow{2}{*}{ Color } & \multicolumn{3}{|c|}{ BRS 216} & \multicolumn{3}{|c|}{ LineA } & \multicolumn{3}{|c|}{ Line B } & \multicolumn{3}{|c|}{ Line C } \\
\hline & $10 \mathrm{~W}$ & $50 \mathrm{~W}$ & $90 \mathrm{~W}$ & $10 \mathrm{~W}$ & $50 \mathrm{~W}$ & $90 \mathrm{~W}$ & $10 \mathrm{~W}$ & $50 \mathrm{~W}$ & $90 \mathrm{~W}$ & $10 \mathrm{~W}$ & $50 \mathrm{~W}$ & $90 \mathrm{~W}$ \\
\hline$L^{*}$ & 45.4 & 55.21 & 57.63 & 63.12 & 50.12 & 56.57 & 63.42 & 63.24 & 56.26 & 29.95 & 51.55 & 60.09 \\
\hline$a^{*}$ & -0.88 & -2.24 & -3.99 & -5.35 & -4.21 & -10.26 & -9.32 & -5.87 & -2.43 & -1.48 & -0.72 & -2.55 \\
\hline$b^{*}$ & 19.96 & 24.22 & 20.94 & 23.13 & 26.73 & 36.38 & 27.06 & 22.49 & 24.57 & 10.32 & 16.92 & 24.65 \\
\hline
\end{tabular}


By evaluating the brightness $\left(L^{*}\right)$ of the sprouts it can be verified that Line $B$ presented a higher index of luminosity with application of 10 and $50 \mathrm{~W}$, followed by Line A with $10 \mathrm{~W}$ (Table 4). High indices of luminosities can make the sprouts more attractive to consumers, since they have a coloration tending to white.

Regarding the parameter $a$ * it was verified that all the soybean sprouts showed a coloring tending to green, and parameter $b$ * tending to yellow. For these parameters, the line A with $90 \mathrm{~W}$ showed the high value, which characterizes better color for sprouts production.

\section{CONCLUSIONS}

In the germination process, all the cultivars presented an increase in the germination, with the increase of ultrasound power where the line A presented greater potential. After the 4 days of germination the line A presented a higher weight of viable sprouts in relation to the quantity of grains used in the process.

Regarding the color parameter a * it was verified that all the soybean sprouts showed a coloring tending to green, and for the parameter $b$ * tending to yellow. For these parameters, the Line $A$ at $90 \mathrm{~W}$ showed the high value, characterizing this line with better color characteristics for sprout production.

For the protein and moisture content, all the cultivars in the different ultrasonic powers had an increase in protein and moisture content. The results of the work subsidize the possibility of recommendation for commercial cultivation of line $A$ and the use the ultrasound to help the germination in sprout production.

\section{RESUMO}

\section{MELHORA NA PRODUÇÃO DE BROTOS DE SOJA COM POTÊNCIA ULTRASSONICA}

O presente trabalho objetivou a aplicação de diferentes potências de ultrassom (10, 50 e 90W) para avaliar a germinação e características dos brotos de soja a partir da cultivar BRS 216 e de 3 linhagens (A, B e C). No teste de germinação a linhagem A foi o que apresentou maior porcentagem de germinação (96\% para $90 \mathrm{~W}$ ). A cultivar BRS 216 e a linhagem A apresentam valores menores de peso e maior rendimento de grãos germinados. Os brotos viáveis que apresentaram o maior peso (para cada $50 \mathrm{~g}$ de grãos de soja) foram: a linhagem A seguida pela BRS 216, linhagem C e B, com diferenças estatísticas $(p<0,05)$ entre si. Nas linhagens B e $C$ verificou-se que apesar de ter ocorrido a germinação, os brotos não apresentaram um bom desenvolvimento. Deste modo, para cada $50 \mathrm{~g}$ de soja da cultivar BRS 216 e Linhagens A, B e C a produção de brotos viáveis foi de 231,$47 ; 237,87 ; 170,74$ e 199,94g, respectivamente, para potência de $90 \mathrm{~W}$. Em relação ao comprimento dos brotos de soja, utilizando a potência de $10 \mathrm{~W}$, a Linhagem $\mathrm{C}$ apresentou maior comprimento. A Linhagem A com aplicação de 90W apresentou melhores características de cor. $\mathrm{O}$ maior valor proteico encontrado foi na cultivar BRS 216, para todas as potências aplicadas. Com este trabalho pode-se concluir que a linhagem A seria a mais indicada para produção de brotos independentemente da potência aplicada.

PALAVRAS CHAVES: CULTIVAR, GERMINAÇÃO, PROTEÍNA, POTENCIA.

\section{REFERENCES}

1 AOAC. Association Of Official Analytical Chemists. Official methods of analysis. Association of Official Analytical Chemists International. Maryland, USA, 2000. 
2 BARCELOS, M.F.P.; VILAS BOAS, E.V.B.; LIMA, M.A.C. Aspectos nutricionais de brotos de soja e de milho combinados. Ciência e Agrotecnologia, v. 26, p. 817-825, 2002.

3 BRASIL. Ministério da Agricultura e Reforma Agrária. Regras para análise de sementes. Brasília: SNDA/DNDV/CLAV, 1992.

4 CANTELLI, K.C.; SCHMITD, J.T.; OLIVEIRA, M.A.; STEFFENS, J.; STEFFENS, C.; LEITE, R. S.; CARRÃO-PANIZZI, M. C. Brotos de linhagens genéticas de soja: avaliação das propriedades físico-químicas. Brazilian Journal of Food Technology, v.20, p.1-10, 2017.

5 CARRÃO-PANIZZI, M. C.; GÓES-FAVONI, S. P.; KIKUCHI, A. Extraction time for soybean isoflavone determination. Brazilian Archives of Biology and Technology: An International Journal, v. 45, p. 515-518, 2002.

6 CARVALHO, N. M.; NAKAGAWA, J. Grãos: ciência, tecnologia e produção. 4. ed. Jaboticabal: Funep, 2000, 588p.

7 CONAB - Companhia Nacional de Abastecimento. Grãos, Safra 2014/2015. Décimo levantamento, julho 2015. Avaliable at: <http://www.conab.gov.br>. Acessed on: 24 Set. 2016.

8 EMBRAPA. Empresa Brasileira De Pesquisa Agropecuária. Centro Nacional de Pesquisa de Soja. Embrapa Soja 2015. Avaliable at:: https://www.embrapa.br/soja/cultivos/soja1/historia. Acessed on: 30 Set. 2015.

9 EMATER - Empresa Paranaense de Assistência Técnica e Extensão Rural. Cultivo de Brotos. Curitiba: Emater/Seab, Apostila técnica, 2007, 48p.

10 LOURES, N.T.P.; NÓBREGA, L.H.P.; COELHO, S.R.M. Análise físico-química, microbiológica e sensorial de brotos de lentilha da variedade Precoz. Acta Scientiarum Agronomy, v. 31, p. 599-606, 2009.

11 MARTINEZ, A.P.C.; MARTINEZ, P.C.C.; SOUZA, M.C.; CANNIATTI BRAZACA, S.G. Alterações químicas em grãos de soja com a germinação. Ciência e Tecnologia de Alimentos, v. 31, p. 23-30, 2011.

12 MIANO, A.C.; PEREIRA, J.D.C.; CASTANHA, N.; JÚNIOR, M.D.D.M.; AUGUSTO, P.E.D. Enhancing mung bean hydration using the ultrasound technology: description of mechanisms and impact on its germination and main components. Scientific Reports, v.6, p.38996. 2016 a. DOI: 10.1038/srep38996.

13 MIANO, A.C.; IBARZ, A.; AUGUSTO, P.E.D. Mechanisms for improving mass transfer in food with ultrasound technology: Describing the phenomena in two model cases. Ultrasonics Sonochemistry, v. 29, p. 413-419, 2016 b. DOI: 10.1016/j. ultsonch.2015.10.020.

14 MIANO, A.C.; IBARZ, A.; AUGUSTO, P.E.D. Ultrasound technology enhances the hydration of corn kernels without affecting their starch properties. Journal of Food Engineering. v. 197, p. 34-43, 2017. DOI: 10.1016/j.jfoodeng.2016.10.024.

15 OLIVEIRA, M.A.; CARRÃO-PANIZZI, M. C.; MANDARINO, J. M. G.; LEITE, R. S. Production of soybean sprouts from the cultivar BRS 216: physical and chemical characterization and acceptability test. Brazilian Journal of Food Technology, v. 16, n. 1 , p. $34-41,2013$.

16 SILVA, J. B. Características de cultivares de soja convencionais e para consumo humano: análises físicas, químicas e sensoriais (sentidos humano e sensores eletrônicos). 2009. 187p. Thesis (Ph.D.) (Doutorado em Ciência de Alimentos) - Universidade Estadual de Londrina. Londrina/Paraná.

17 TACO. Tabela Brasileira de Composição de Alimentos. 4ª edição Revisada e ampliada, Campinas - São Paulo, 2011.

18 YANG, H.; GAO, J.; YANG, A.; CHEN, H. The ultrasound-treated soybean seeds improve edibility and nutritional quality of soybean sprouts. Food Research International, v.77, p. 704-710, 2015.

19 VIEIRA, R.F.; LOPES, J.D.S. Produção de Brotos Comestíveis: Feijão Moyashi, Alfafa, Trevo, Rabanete e Brócolis. Viçosa: CPT, 2001. 108p.

20 VILAS BOAS, E.V.B.; BARCELOS, M.F.P.; LIMA, M.A.C. Tempo de germinação e característica físicas, químicas e sensoriais dos brotos de soja e de milho combinado nas formas isoladas e combinadas. Ciência e Agrotecnologia, $v$. 26, n. 1, p. 148-156, 2002.

\section{ACKNOWLEGMENTS}

The authors thank Embrapa and CNPq - National Brazilian Research Council for the support the work. 